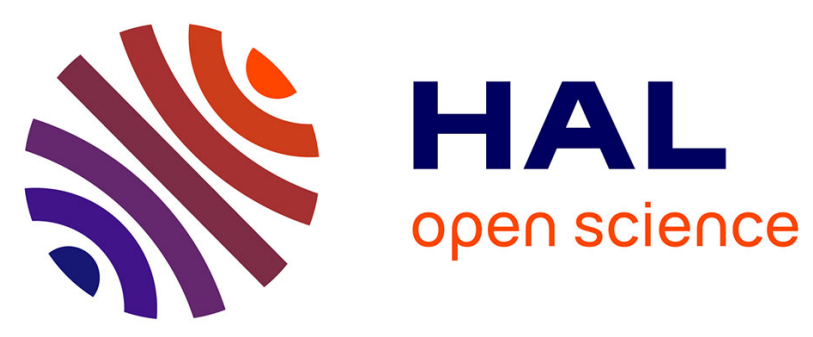

\title{
Palladium mediated direct coupling of silylated arylalkynes with propargylic chlorides: an efficient access to functionalized conjugated allenynes
}

Delphine Girard, Sylvie Broussous, Olivier Provot, Jean-Daniel Brion, Mouad Alami

\section{To cite this version:}

Delphine Girard, Sylvie Broussous, Olivier Provot, Jean-Daniel Brion, Mouad Alami. Palladium mediated direct coupling of silylated arylalkynes with propargylic chlorides: an efficient access to functionalized conjugated allenynes. Tetrahedron Letters, 2007, 48 (34), pp.6022-6026. 10.1016/j.tetlet.2007.06.079 . hal-02394606

\section{HAL Id: hal-02394606 https://hal.science/hal-02394606}

Submitted on 4 Dec 2019

HAL is a multi-disciplinary open access archive for the deposit and dissemination of scientific research documents, whether they are published or not. The documents may come from teaching and research institutions in France or abroad, or from public or private research centers.
L'archive ouverte pluridisciplinaire HAL, est destinée au dépôt et à la diffusion de documents scientifiques de niveau recherche, publiés ou non, émanant des établissements d'enseignement et de recherche français ou étrangers, des laboratoires publics ou privés. 
archives-ouvertes

\section{Palladium mediated direct coupling of silylated arylalkynes with propargylic chlorides: an efficient access to functionalized conjugated allenynes}

Delphine Girard, Sylvie Broussous, Olivier Provot, Jean-Daniel Brion, Mouad Alami

\section{To cite this version:}

Delphine Girard, Sylvie Broussous, Olivier Provot, Jean-Daniel Brion, Mouad Alami. Palladium mediated direct coupling of silylated arylalkynes with propargylic chlorides: an efficient access to functionalized conjugated allenynes. Tetrahedron Letters, Elsevier, 2007, 48 (34), pp.6022-6026. 10.1016/j.tetlet.2007.06.079 . hal-02394606

\section{HAL Id: hal-02394606 \\ https://hal.archives-ouvertes.fr/hal-02394606}

Submitted on 4 Dec 2019

HAL is a multi-disciplinary open access archive for the deposit and dissemination of scientific research documents, whether they are published or not. The documents may come from teaching and research institutions in France or abroad, or from public or private research centers.
L'archive ouverte pluridisciplinaire HAL, est destinée au dépôt et à la diffusion de documents scientifiques de niveau recherche, publiés ou non, émanant des établissements d'enseignement et de recherche français ou étrangers, des laboratoires publics ou privés. 


\title{
Palladium mediated direct coupling of silylated arylalkynes with propargylic chlorides: An efficient access to functionalized conjugated allenynes
}

\author{
Delphine Girard ${ }^{\S}$, Sylvie Broussous ${ }^{\S}$, Olivier Provot, ${ }^{*}$ Jean-Daniel Brion and Mouâd Alami* \\ Univ Paris-Sud, CNRS, BioCIS, UMR 8076, Laboratoire de Chimie Thérapeutique, Faculté de Pharmacie, rue J.B. Clément 92296 \\ Châtenay-Malabry Cedex, France
}

\begin{abstract}
Pd} / \mathrm{Cu}$-catalyzed one-pot reaction of 1-trimethylsilyl-2-arylalkynes with propargylic chlorides in the presence of TBAF is described. The present new procedure is applicable to a wide range of silylated arylalkynes with both electron-withdrawing and electrondonating substituents. Functionalized allenynes can thus be obtained in good yields without prior deprotection of the alkynes
\end{abstract}

In the course of a program devoted to the stereo- and regioselective addition of metalloid hydrides to unsymetrical alkynes including arylalkynes ${ }^{1}$ and enynes ${ }^{2}$, we were interested to prepare effectively aryl allenynes $\mathbf{1}$ bearing various substituents on the aromatic ring. A survey of the literature revealed that few methods for the preparation of this class of compounds have been developed. Among various routes, ${ }^{3}$ the $\mathrm{Pd} / \mathrm{Cu}$-catalyzed reaction of terminal alkynes with either allenyl bromides, ${ }^{4}$ or propargylic species including carbonates, ${ }^{5}$ halides, tosylates and acetates ${ }^{6}$ is the most popular and attractive method. However, the described procedures are only based on the coupling with available terminal alkylalkynes or with phenylacetylene. On the contrary, functionalized terminal arylalkynes have not been investigated in these Pd-catalyzed reactions, probably because their preparation required, from aryl halides, Sonogashira coupling ${ }^{7}$ with trimethylsilylacetylene followed by a desilylation step. Moreover, such terminal alkynes are sensitive substrates when bearing an electron-withdrawing substituent $(\mathrm{CN}$, $\mathrm{NO}_{2}, \mathrm{CF}_{3} \ldots$ ) on the aromatic ring. ${ }^{8}$ It obviously would be interesting and economical to be able to engage functionalized trimethylsilylalkynes $\mathbf{2}$ in these coupling reactions. Although the coupling of trimethylsilylalkynes with vinyl and aryl halides is well-known, ${ }^{9}$ to our knowledge, nothing is described on their coupling with propargylic halides. We present in this communication, a mild and convenient one-pot procedure for the direct coupling of 1-trimethylsilyl-2-arylalkynes $\mathbf{2}$ with

$\S$ contributed equally to this work "Corresponding authors. olivier.provot@u-psud.fr and/or mouad.alami@u-psud.fr

Keywords : palladium, coupling, allenynes, silylated alkynes, propargylic chlorides. propargylic chlorides $\mathbf{3}$ to provide efficiently conjugated allenynes 1 (Scheme 1).

We have studied the reaction of arylalkyne $\mathbf{2 a}$ as a model substrate with propargylic species $\mathbf{3}$ and the results are summarized in Table 1. Preliminary experiments have been carried out using Linstrumelle's method, ${ }^{6}$ using silylated alkyne $2 \mathbf{a}$ (1.2 eq), propargylic chloride $\mathbf{3}$ (1 eq), TEA (1.5

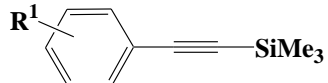

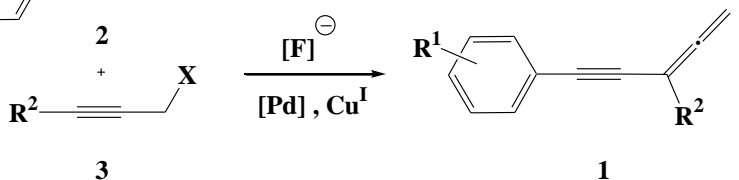

$\mathrm{R}^{1}=\mathrm{OMe}, \mathrm{CO}_{2} \mathrm{Et}, \mathrm{CN}, \mathrm{NO}_{2}, \mathrm{Cl}, \ldots \quad \mathrm{R}^{2}=$ Aryl, Alkyl

Scheme 1.

eq), and TBAF (1 eq) in DMF at room temperature. Under these conditions, the reaction afforded moderate yields of allenyne 1a together with significant amounts of the homocoupling diyne $4^{10}$ easily separated by flash column chromatography. The ratio $\mathbf{2 a / 3}$ was examined to decrease the yield of by-product 4 and after optimization it was reversed and fixed to 1/1.2. Accordingly, the coupling reaction afforded a mixture of $\mathbf{1 a} / \mathbf{4}$ in a $72 / 28$ ratio (entry 1). Replacing TEA by a mineral base $\left(\mathrm{K}_{2} \mathrm{CO}_{3}\right)$, resulted in a similar ratio but in a shorter reaction time ( $2 \mathrm{~h}$, entry 2$)$. The nature of the fluorine source was next investigated and we found that $\mathrm{CsF}$ was effective too but less reactive than 
TBAF (entry 3). On the contrary, the reaction provided poor yields with $\mathrm{KF}$ and it failed completely with $\mathrm{LiF}$ (entries 4 and 5). Seeing that the nature of the base had apparently no effect, we have carried out an attempt without any base and we were pleased to observe a complete conversion of the starting material 2a within $1 \mathrm{~h}$ and allenyne 1a was isolated in a $66 \%$ yield (entry 6 ).
Under these experimental conditions no skipped diyne resulting from a formal $\mathrm{S}_{\mathrm{N}} 2$ was observed. In order to avoid the formation of the diyne by-product $4, \operatorname{Pd}(0)$ catalysts $\left(\mathrm{Pd}\left(\mathrm{PPh}_{3}\right)_{4}, \mathrm{Pd}(\mathrm{dba})_{2}+2 \mathrm{PPh}_{3}\right)$ were evaluated in this coupling but did not gave better results (entries 7 and 8) indicating that diyne $\mathbf{4}$ did not resulted

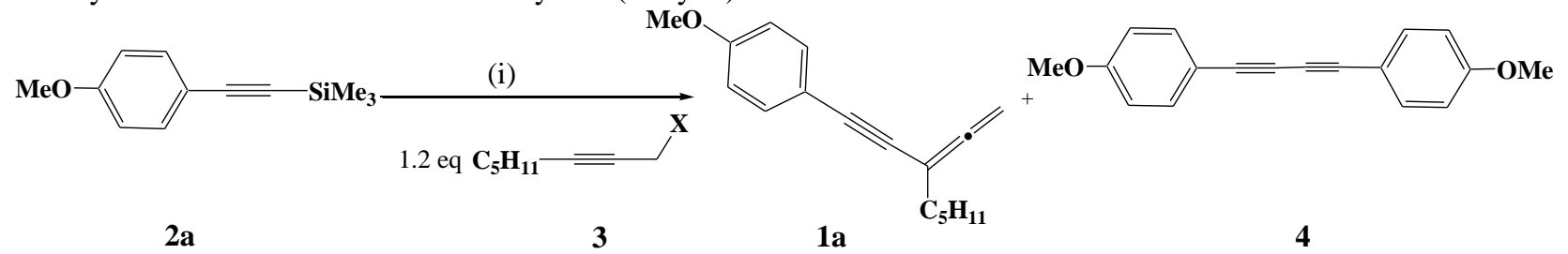

(i) 0.05 eq $[\mathrm{Pd}], 1$ eq $\left[\mathrm{Cu}^{\mathrm{I}}\right], 1$ eq $[\mathrm{F}]$, Base, DMF, $20^{\circ} \mathrm{C}$, time

Table 1. $\mathrm{Pd} / \mathrm{Cu}$-catalyzed coupling reaction of silylated arylalkyne 2a with propargylic compounds 3: Synthesis of 1a

\begin{tabular}{|c|c|c|c|c|c|c|c|c|c|}
\hline Entry & Base & {$\left[\mathbf{F}^{-}\right]$} & [Pd] & {$\left[\mathbf{C u}^{\mathrm{I}}\right]$} & $\mathbf{X}$ & Time (h) & Conv. $^{{ }^{\mathrm{a}}}$ & $1 a / 4$ & $\begin{array}{l}\text { Yield }^{\mathrm{b}} \text { of } \\
\text { 1a (\%) }\end{array}$ \\
\hline 1 & TEA & TBAF & $\mathbf{P d C l}_{2}\left(\mathbf{P P h}_{3}\right)_{2}$ & $\mathrm{CuI}$ & $\mathrm{Cl}$ & 3 & 100 & $72 / 28$ & 44 \\
\hline 2 & $\mathrm{~K}_{2} \mathrm{CO}_{3}$ & TBAF & $"$ & $"$ & $"$ & 2 & 100 & $70 / 30$ & 48 \\
\hline 3 & $"$ & CsF & $"$ & $"$ & $"$ & 6 & 66 & $75 / 25$ & nd \\
\hline 4 & $"$ & $\mathbf{K F}$ & $"$ & $"$ & $"$ & 72 & 72 & $29 / 71$ & nd \\
\hline 5 & $"$ & LiF & $"$ & $"$ & $"$ & 96 & 50 & 0/100 & $\mathbf{0}$ \\
\hline 6 & none & TBAF & $"$ & $\mathrm{CuI}^{\mathrm{c}}$ & $"$ & 1 & 100 & $91 / 9$ & 66 \\
\hline 7 & $"$ & $"$ & $\mathbf{P d}\left(\mathbf{P P h}_{3}\right)_{4}$ & $"$ & $"$ & 1 & 100 & 90/10 & 58 \\
\hline 8 & $"$ & $"$ & $\operatorname{Pd}(\mathrm{dba})_{2}+2 \mathrm{PPh}_{3}$ & $"$ & $"$ & 1 & 100 & $56 / 44$ & 26 \\
\hline 9 & $"$ & $"$ & $\mathbf{P d C l}_{2}\left(\mathbf{P P h}_{3}\right)_{2}$ & $\mathrm{CuCl}$ & $"$ & 24 & 100 & $55 / 45$ & 23 \\
\hline 10 & $"$ & $"$ & $"$ & $\mathrm{CuBr}$ & $"$ & 24 & 75 & $33 / 67$ & nd \\
\hline 11 & $"$ & $"$ & $"$ & $\mathrm{CuCN}$ & $"$ & 5 & 13 & $66 / 34$ & nd \\
\hline 12 & $"$ & $"$ & $"$ & $\operatorname{CuTC}^{\mathrm{d}}$ & $"$ & 1 & 100 & $45 / 55$ & 19 \\
\hline 13 & $"$ & $"$ & $"$ & $\mathrm{CuI}$ & OAc & 3.5 & 100 & 0/100 & o \\
\hline 14 & $"$ & $"$ & $"$ & $"$ & $\mathrm{OPO}(\mathrm{OEt})_{2}$ & 2 & 67 & $86 / 14$ & nd \\
\hline 15 & $"$ & $"$ & $"$ & $"$ & OTs & 1.75 & 100 & $80 / 20$ & 45 \\
\hline 16 & $"$ & $"$ & $"$ & $"$ & $\mathrm{Br}$ & 1.5 & 95 & $80 / 20$ & nd \\
\hline
\end{tabular}

${ }^{\mathrm{a}}$ The conversion was measured by ${ }^{1} \mathrm{H}$ NMR analysis and is based on terminal alkyne.

${ }^{\mathrm{b}}$ Isolated yield.

${ }^{c}$ When the reaction was carried out for $1 \mathrm{~h}$ with 0.1 eq of $\mathrm{CuI}$ a mixture of terminal alkyne/1a/4 was obtained in the ratio $44 / 19 / 37$. With 1.5 eq of CuI, the ratio became 14/79/7.

${ }^{\mathrm{d}}$ Copper(I) thiophene-2-carboxylate.

only from the reduction of the catalyst $(\mathrm{Pd}(\mathrm{II}) \rightarrow \mathrm{Pd}(0))$. Because $\operatorname{Pd}(0)$ catalysts had to be stored under argon and are more expensive than $\mathrm{PdCl}_{2}\left(\mathrm{PPh}_{3}\right)_{2}$ we have carried on this study with this catalyst and tested the influence of various $\mathrm{Cu}(\mathrm{I})$ salts (entries 9-12). Unfortunately, longer reaction times, by comparison with $\mathrm{CuI}$, were required and as a probable consequence, the quantity of by-product Table 2. Coupling of trimethylsilyl-1-alkynes with propargylic chlorides: Synthesis of allenynes $\mathbf{1}$

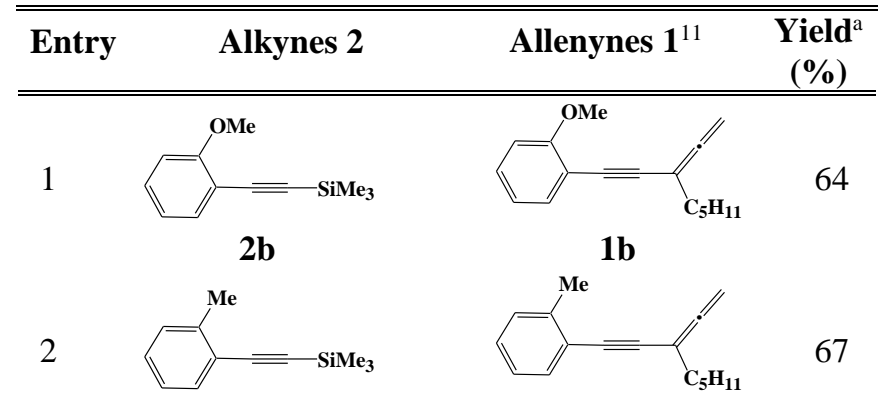


2c<smiles>CCCCCCC#Cc1cc(OC)c(OC)c(OC)c1</smiles>

4

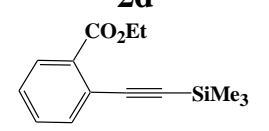

$2 \mathrm{e}$

5<smiles>CCCCC(=O)c1ccc(C#CNS(=O)(=O)c2ccccc2)cc1</smiles>

2f

6

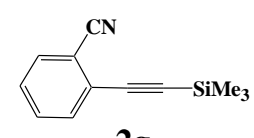

$2 \mathrm{~g}$

7

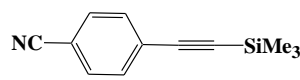

$2 h$

8

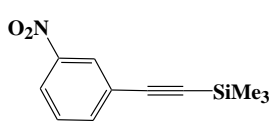

$2 i$

9

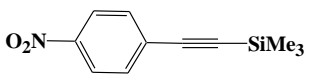

$2 \mathbf{j}$

10

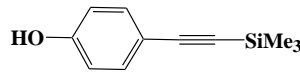

2k

11

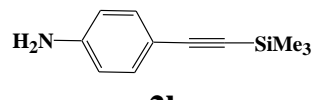

2I

12

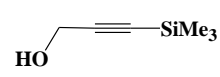

$2 \mathrm{~m}$

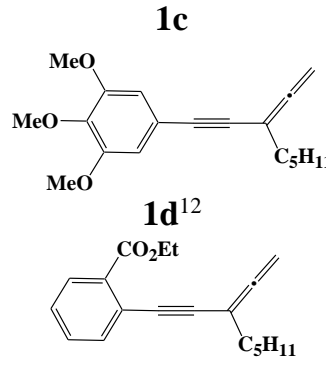

1e
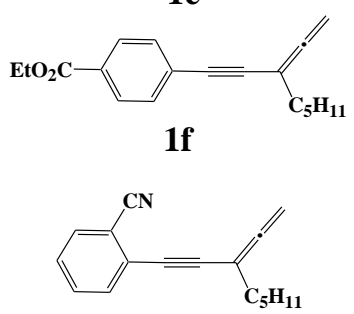

$1 g$

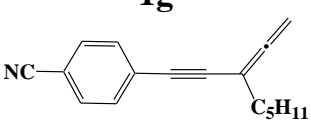

$1 h$

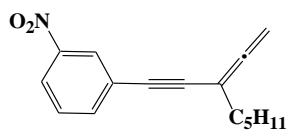

$\mathbf{1 i}^{12}$

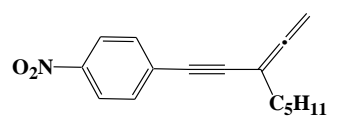

$\mathbf{1 j}^{12}$

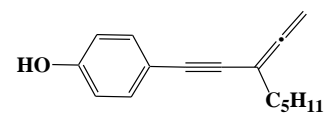

$1 k$

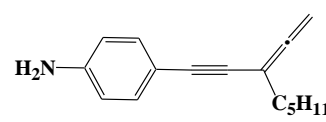

11

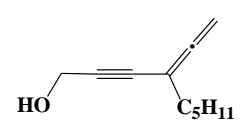

$1 \mathrm{~m}$

\section{0}

${ }^{a}$ isolated yield

${ }^{\mathrm{b}}$ not optimized yield

diyne 4 was increased (entries 9-12). The role of the leaving group on the propargylic partner was examined in the next set of experiments. Under the previous experimental conditions, propargylic acetate was unreactive (entry 13). Otherwise, tosylate, bromide and phosphonate were effective substrates for the synthesis of $1 \mathrm{a}$ but the reaction proceeded slowly without improvement in the ratio allenyne 1a versus diyne 4 (entries 14-16). Finally, a number of solvents were investigated in this reaction (dioxane, EtOAc, NMP, toluene and $\mathrm{MeCN}$ ), but DMF was found to be the best solvent with regard to reaction time and minimizing the yield of homocoupled by-product 4 .

To demonstrate the versatility of the method, this one-pot reaction was then applied to various substituted arylalkynes and propargylic chlorides. Thus, we screened

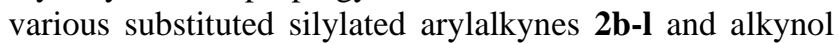
2m for their $\mathrm{Pd} / \mathrm{Cu}$-catalyzed coupling with propargylic chlorides and the results are shown in Table 2.

Performing the reaction with variously substituted arylalkynes resulted in the formation of allenynes $\mathbf{1}$ in good yields. Electron-donating and electron-withdrawing substituents on the aromatic ring did not interfere with the outcome of the present reaction and similar yields were obtained (entries 1-11). Similarly, the results in Table 2 showed that changing the substituent's position on the aromatic ring from para to ortho (entries 4-5 and 6-7) or meta to para (entries 8 and 9) did not affect the yield of the reaction. The presence of a free hydroxyl or amino group did not impart the effciency of this coupling as demonstrated by the coupling of $\mathbf{2 k}$ and 21 with propargylic chloride $\mathbf{3}$ (entries 10 and 11). Finally, one cross coupling was successfully attempted between 1chloro-2-octyne and silylated propargylic alcohol $\mathbf{2 m}$ leading, as expected, to the corresponding allenyne $\mathbf{1 m}$ with a $64 \%$ unoptimized isolated yield (entry 12). Thus this result revealed that aliphatic silylated alkynes can also be utilized with yields as good as those from their aromatic counterparts.

From a mechanistic point of view, it is reasonable to think that the reaction proceeded firstly via a $\sigma$-allenic palladium complex $\mathbf{I}^{13}$ which resulted from the oxidative addition of the propargylic chloride to the catalyst (Scheme 2). At this stage, two nucleophilic species could enter the Pd catalytic cycle: a pentacoordinated fluorosilicate $\mathbf{I I}^{14}$ resulting from the activation of the silane 2 by TBAF or, in the presence of CuI, a trans metallated copper acetylide III. To define as well as possible the nature of the reactive $\mathrm{Nu}^{-}$species, we have achieved an experiment without copper iodide. After stirring for $1 \mathrm{~h},{ }^{15}$ only $26 \%$ of allenyne $\mathbf{1}$ was isolated indicating clearly that $\mathrm{CuI}$ remarkably improved the reactivity of the $\mathrm{Nu}^{-}$. Consequently, species IV would certainly resulted through the nucleophilic copper acetylide III. 


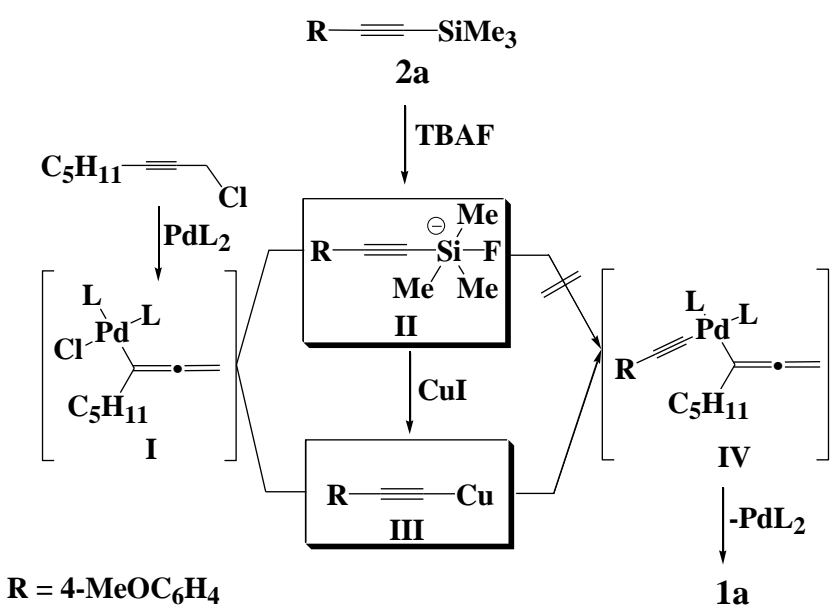

Scheme 2

In summary, the $\mathrm{Pd} / \mathrm{Cu}$-catalyzed coupling reaction of propargylic chlorides with various silylated alkynes has been achieved in a one-pot procedure in the presence of TBAF. This methodology opens a useful and direct route to a series of allenynes $\mathbf{1}$ bearing various substituents on the aromatic ring, particularly on the ortho position. A variety of substituted aryl allenynes $\mathbf{1}$ have been prepared according to this very simple procedure and metalcatalyzed hydrometallation of substituted allenynes $\mathbf{1}$ are currently under progress.

Typical procedure: Under a nitrogen atmosphere, alkyne 2a (106 mg; $0.52 \mathrm{mmol}$ ) was added dropwise at room temperature to a suspension of $\mathrm{PdCl}_{2}\left(\mathrm{PPh}_{3}\right)_{2}(18.3 \mathrm{mg}$; $0.026 \mathrm{mmol}$ ), CuI (99 mg; $0.52 \mathrm{mmol}$ ), 1-chloro-2-octyne (90 mg; $0.62 \mathrm{mmol})$ and TBAF ( $1 \mathrm{~N}$ in THF $520 \mu \mathrm{L} ; 0.52$ $\mathrm{mmol})$ in degazed DMF ( $2 \mathrm{~mL})$. The initially slightly yellow solution gradually darkened. After $1 \mathrm{~h}$, diethyl ether $(5 \mathrm{~mL})$ was added to the reaction mixture which was filtered over a pad of celite. The organic layer was washed successively with a saturated $\mathrm{NH}_{4} \mathrm{Cl}$ solution twice and water. After drying over sodium sulfate, filtration and solvent evaporation, a yellow oil was obtained. Flash chromatography over neutral aluminium oxide provided pure product $1 \mathbf{1}^{16}$ as a colorless oil $(82 \mathrm{mg}$; $0.34 \mathrm{mmol}$; $66 \%)$.

\section{Acknowledgments}

The CNRS is gratefully acknowledged for financial support of this research and the MNSER for a doctoral fellowship to D.G. We wish to thank also l'Institut Jérôme Lejeune for a doctoral fellowship to S.B.

\section{References}

1 (a) Hamze, A.; Provot, O.; Alami, M.; Brion, J.D. Org. Lett. 2005, 7, 5625-5628. (b) Liron, F.; Gervais, M.; Peyrat, J.-F.; Alami, M.; Brion, J.-D. Tetrahedron Lett. 2003, 44, 2789-2794. (c) Alami, M.; Liron, F.; Gervais, M.; Peyrat, J.-F.; Brion, J.-D. Angew. Chem. Int. Ed. 2002, 41, 1578-1580. (d) Liron, F.; Le Garrec, P.; Alami, M. Synlett 1999, 246-248.
2 (a) Hamze, A.; Provot, O.; Alami, M.; Brion, J.D. J. Org. Chem. 2007, 72, in press. (b) Bujard, M. Ferri, F.; Alami, M. Tetrahedron Lett. 1998, 39, 4243-4246. (c) Ferri, F.; Alami, M. Tetrahedron Lett. 1996, 37, 7971-7974. (d) Alami, M.; Ferri, F. Synlett 1996, 755-756.

3 (a) Aoyagi, S.; Koyanagi, M.; Takahashi, M.; Shimada, K.; Takikawa, Y. Tetrahedron Lett. 2007, 48, 1915-1918. (b) Maurer, H.; Hopf, H. Eur. J. Org. Chem. 2005, 2702-2707. (c) Ruitenberg, K.; Meijer, J.; Bullee, R.J.; Vermeer, P. J. Organometal. Chem. 1981, 217, 267-271. (d) Ruitenberg, K.; Kleijn, H.; Elsevier, C.J.; Meijer, J.; Vermeer, P. Tetrahedron Lett. 1981, 22, 1451-1454. (e) Baker, C.S.L.; Landor, P.D.; Landor, S.R. J. Chem. Soc. 1965, 4659-4664

4 Jeffery-Luong, T.; Linstrumelle, G. Synthesis 1983, 32-34.

5 (a) Hayashi, M.; Saigo, K. Tetrahedron Lett. 1997, 35, 6241-6244. (b) Mandai, M.; Murayama, H.; Nakata, T.; Yamaoki, H.; Ogawa, M.; Kawada, M.; Tsuji, J. J. Organomet. Chem. 1991, 417, 305-311. (c) Mandai, T.; Nakata, T.; Murayama, H.; Yamaoki, H.; Ogawa, M.; Kawada, M.; Tsuji, J. Tetrahedron Lett. 1990, 31, 7179-7182.

6 (a) Condom-Gueugnot, S.; Linstrumelle, G. Tetrahedron 2000, 56, 1851-1857. (b) Gueugnot, S.; Linstrumelle, G. Tetrahedron Lett. 1993, 34, 3853-3856.

7 Sonogashira, K.; Tohda, Y.; Hagihara, N. Tetrahedron Lett. 1975, 16, 4467-4470.

8 Kwatra, M.M.; Simon, D.Z.; Salvador, R.L.; Cooper, P.D. J. Med. Chem. 1978, 21, 253-257.

9 (a) Littke, A.; Fu, G. Angew. Chem. Int. Ed. 2002, 41, 4176-4211. (b) Hatanaka, Y.; Hiyama, T. J. Org. Chem. 1988, 53, 918-920.

10 Nishihara, Y.; Ikegashira, K.; Hirabayashi, K.; Ando, J.; Mori, A.; Hiyama, T. J. Org. Chem. 2000, 65, 17801787.

11 Allenynes $\mathbf{1}$ are sensitive substrates and must be stored under argon at $-20^{\circ} \mathrm{C}$

12 All new compounds allenynes 1 were characterized by ${ }^{1} \mathrm{H}$ NMR (300 $\mathrm{MHz}),{ }^{13} \mathrm{C}$ NMR $(75 \mathrm{MHz})$, and elemental analyses.

Selected data for allenynes:

1d: ${ }^{1} \mathrm{H}$ NMR $\left(300 \mathrm{MHz}, \mathrm{CDCl}_{3}\right) \delta 0.90(\mathrm{t}, 3 \mathrm{H}, J=7.0 \mathrm{~Hz}), 1.30-1.40$ $(\mathrm{m}, 4 \mathrm{H}), 1.50-1.60(\mathrm{~m}, 2 \mathrm{H}), 2.15-2.25(\mathrm{~m}, 2 \mathrm{H}), 3.83(\mathrm{~s}, 9 \mathrm{H}), 4.97(\mathrm{t}$, $2 \mathrm{H}, J=2.8 \mathrm{~Hz}), 6.66(\mathrm{~s}, 2 \mathrm{H}),{ }^{13} \mathrm{C}$ NMR $\left(75 \mathrm{MHz}, \mathrm{CDCl}_{3}\right) \delta \square 14.0$ $\left(\mathrm{CH}_{3}\right), 22.4\left(\mathrm{CH}_{2}\right), 27.5\left(\mathrm{CH}_{2}\right), 31.1\left(\mathrm{CH}_{2}\right), 33.3\left(\mathrm{CH}_{2}\right), 56.2(2$, $\left.\mathrm{OCH}_{3}\right), 60.9\left(\mathrm{OCH}_{3}\right), 76.8\left(\mathrm{CH}_{2}\right), 83.6(\mathrm{C}), 89.9(\mathrm{C}), 91.4(\mathrm{C}), 108.7$ $(2 \mathrm{CH}), 118.6(\mathrm{C}), 138.7(\mathrm{C}), 153.0(2 \mathrm{C}), 213.7(\mathrm{C})$.

1i: ${ }^{1} \mathrm{H}$ NMR $\left(300 \mathrm{MHz}, \mathrm{CDCl}_{3}\right) \delta 0.91(\mathrm{t}, 3 \mathrm{H}, J=7.0 \mathrm{~Hz}), 1.30-1.40$ $(\mathrm{m}, 4 \mathrm{H}), 1.50-1.65(\mathrm{~m}, 2 \mathrm{H}), 2.15-2.25(\mathrm{~m}, 2 \mathrm{H}), 5.02(\mathrm{t}, 2 \mathrm{H}, J=2.8$ $\mathrm{Hz}), 7.47(\mathrm{t}, 1 \mathrm{H}, J=7.8 \mathrm{~Hz}), 7.71(\mathrm{dt}, 1 \mathrm{H}, J=7.8 \mathrm{~Hz}, J=0.9 \mathrm{~Hz})$, $8.10-8.15(\mathrm{~m}, 1 \mathrm{H}), 8.26(\mathrm{t}, 1 \mathrm{H}, J=1.8 \mathrm{~Hz}) .{ }^{13} \mathrm{C} \mathrm{NMR}(75 \mathrm{MHz}$, $\left.\mathrm{CDCl}_{3}\right) \delta \square 14.0\left(\mathrm{CH}_{3}\right), 22.4\left(\mathrm{CH}_{2}\right), 27.5\left(\mathrm{CH}_{2}\right), 31.1\left(\mathrm{CH}_{2}\right), 33.0$ $\left(\mathrm{CH}_{2}\right), 77.1\left(\mathrm{CH}_{2}\right), 87.6(\mathrm{C}), 88.8(\mathrm{C}), 89.4(\mathrm{C}), 122.6(\mathrm{CH}), 125.4$ (C), $126.2(\mathrm{CH}), 129.2(\mathrm{CH}), 137.0(\mathrm{CH}), 148.1(\mathrm{C}), 214.0(\mathrm{C})$.

1j: ${ }^{1} \mathrm{H}$ NMR $\left(300 \mathrm{MHz}, \mathrm{CDCl}_{3}\right) \delta 0.91(\mathrm{t}, 3 \mathrm{H}, J=7.0 \mathrm{~Hz}), 1.28-1.40$ $(\mathrm{m}, 4 \mathrm{H}), 1.50-1.60(\mathrm{~m}, 2 \mathrm{H}), 2.15-2.25(\mathrm{~m}, 2 \mathrm{H}), 5.03(\mathrm{t}, 2 \mathrm{H}, J=2.8$ $\mathrm{Hz}), 7.55(\mathrm{~d}, 2 \mathrm{H}, J=9.0 \mathrm{~Hz}), 8.17(\mathrm{~d}, 2 \mathrm{H}, J=9.0 \mathrm{~Hz}) .{ }^{13} \mathrm{C}$ NMR $(75$ $\left.\mathrm{MHz}, \mathrm{CDCl}_{3}\right) \delta \square 14.0\left(\mathrm{CH}_{3}\right), 22.4\left(\mathrm{CH}_{2}\right), 27.5\left(\mathrm{CH}_{2}\right), 31.0\left(\mathrm{CH}_{2}\right)$, $33.0\left(\mathrm{CH}_{2}\right), 77.2\left(\mathrm{CH}_{2}\right), 89.5(\mathrm{C}), 89.6(\mathrm{C}), 90.5(\mathrm{C}), 123.5(2 \mathrm{CH})$, $130.5(\mathrm{C}), 132.0(2 \mathrm{CH}), 146.8(\mathrm{C}), 214.1(\mathrm{C})$.

13 Elsevier, C.; Stehouwer, P.; Westmijze, H.; Vermeer, P. J. Org. Chem. 1983, 48, 1103-1105.

14 (a) Hiyama, T. In Metal-Catalyzed Cross-Coupling Reactions; Diederich, F.; Stang, P.J., Eds.; Wiley: Weinheim, 1997; 421-453. (b) Halbes, U.; Bertus, P.; Pale, P. Tetrahedron Lett. 2001, 42, 86418644. (c) Hiyama, T.; Hatanaka, Y. Pure Appl. Chem. 1994, 66, 1471-1478. (d) Kumada, M. Tetrahedron Lett. 1978, 19, 2161-2164.

15 Without $\mathrm{CuI}$ and after stirring for $25 \mathrm{~h}$, the conversion yield based on terminal alkyne was estimated at $45 \%$.

16 1a: ${ }^{1} \mathrm{H}$ NMR $\left(300 \mathrm{MHz}, \mathrm{CDCl}_{3}\right) \delta 0.90$ (t, $\left.3 \mathrm{H}, J=6.8 \mathrm{~Hz}\right), 1.30-1.60$ $(\mathrm{m}, 6 \mathrm{H}), 2.15-2.20(\mathrm{~m}, 2 \mathrm{H}), 3.80(\mathrm{~s}, 3 \mathrm{H}), 4.96(\mathrm{t}, 2 \mathrm{H}, J=3.0 \mathrm{~Hz})$, $6.83(\mathrm{~d}, 2 \mathrm{H}, J=8.8 \mathrm{~Hz}), 7.37(\mathrm{~d}, 2 \mathrm{H}, J=8.8 \mathrm{~Hz}),{ }^{13} \mathrm{C} \mathrm{NMR}(75$ $\left.\mathrm{MHz}, \mathrm{CDCl}_{3}\right) \delta \square 14.1\left(\mathrm{CH}_{3}\right), 22.4\left(\mathrm{CH}_{2}\right), 27.5\left(\mathrm{CH}_{2}\right), 31.1\left(\mathrm{CH}_{2}\right)$, $33.4\left(\mathrm{CH}_{2}\right), 55.3\left(\mathrm{OCH}_{3}\right), 76.6\left(\mathrm{CH}_{2}\right), 83.1(\mathrm{C}), 90.1(\mathrm{C}), 91.4(\mathrm{C})$, $113.9(2 \mathrm{CH}), 115.7(\mathrm{C}), 132.8(2 \mathrm{CH}), 159.4(\mathrm{C}), 213.6(\mathrm{C})$. 